\title{
A 30,000-YEAR POLLEN AND RADIOCARBON RECORD FROM HIGHLAND SUMATRA AS EVIDENCE FOR CLIMATIC CHANGE
}

\author{
B. K. MALONEY and F. G. MCCORMAC
}

Palaeoecology Centre, The Queen's University, Belfast BT7 1NN, Northern Ireland

\begin{abstract}
We examine the pollen analytical and ${ }^{14} \mathrm{C}$ sequences from two Sumatra highland sites, Pea Bullok $\left(2^{\circ} 15^{\prime} \mathrm{N}\right.$, $\left.99^{\circ} 02^{\prime} \mathrm{E}\right)$ and Danau di-Atas $\left(1^{\circ} 04^{\prime} \mathrm{S}, 100^{\circ} 46^{\prime} \mathrm{E}\right)$. The pollen diagrams do not correlate particularly well, possibly because two of the samples from Danau di-Atas analyzed by radioactive decay counting earlier should be infinite. Other complications are differences in the type of site, local topography, pollen sums used and difficulty in distinguishing between pollen taxa from local and regional vegetation. The older material from Pea Bullok was AMS dated.
\end{abstract}

\section{INTRODUCTION}

Pea Bullok is located on a plateau at ca. 1400 -m elevation $2 \mathrm{~km}$ north of Siborongborong $\left(2^{\circ} 15^{\prime} \mathrm{N}\right.$, $\left.9902^{\prime} \mathrm{E}\right)$ in the Toba Highlands of north Sumatra, and Danau di-Atas $\left(1^{\circ} 04^{\prime} \mathrm{S}, 100^{\circ} 46^{\prime} \mathrm{E}\right)$ is at 1535 $\mathrm{m}$ asl in central Sumatra. Pea Bullok appears to be an extinct volcanic crater and is infilled almost to the rim by peats, but Danau di-Atas is a rift valley lake ca. $6 \mathrm{~km}$ long by $3 \mathrm{~km}$ wide, bordered in places by a marginal peat swamp from which the core used in pollen analysis was extracted (Newsome and Flenley 1988).

The sites are important, as they are the only ones from Sumatra that span the whole of the last glacial period. Because their pollen records should give evidence for profound vegetation changes, with implications for climate change and the environmental impact of humans at a time of their dispersal throughout Southeast Asia, it is important that the sediments be well dated. Two cores from Pea Bullok underwent pollen analysis, one (A) from the edge of the swamp and the other (B) from the center. Table 1 lists the 18 available ${ }^{14} \mathrm{C}$ dates: 2 University of Oxford (OxA) accelerator mass spectrometer (AMS) dates and 16 conventional University of Belfast (UB) dates. One core from Danau di-Atas was examined for pollen by Newsome and Flenley (1988) and 10 samples were dated by the National Environment Research Council (NERC) Laboratory, East Kilbride (SRR) and the Geochron laboratories, Boston (GX), at four different times (Table 1). The Danau di-Atas core was 16.5 $\mathrm{m}$ long, and inverted dates were derived from samples taken below $13 \mathrm{~m}$ depth. The 8-m-long Pea Bullok Core $A$ has one inverted date at $2.20-2.30 \mathrm{~m}$ depth and one with a bomb spike. Pea Bullok Core $\mathrm{B}$ is $3.5 \mathrm{~m}$ long.

\section{Present-Day Climate, Vegetation and Soils}

Siborongborong, the meteorological recording station nearest Pea Bullok, has a well-distributed mean annual rainfall of $c a .2000 \mathrm{~mm}$ (Boerma 1925), sufficient for forest development. At Danau di-Atas, ca. $400 \mathrm{~km}$ away, rainfall totals ca. $2000-2500 \mathrm{~mm}$, with the drier months from May to September (Fontanel and Chantefort 1978). Precise temperature figures are unavailable, but the mean annual temperatures in both areas are probably $c a .18-20^{\circ} \mathrm{C}$ (Braak 1925), with average daily ranges larger than the annual range of mean temperature.

The Toba Plateau of North Sumatra is now largely deforested, but remnant lower montane forest is present ca. $3 \mathrm{~km}$ west of Pea Bullok. This includes trees of the Fagaceae, Lauraceae and Myrtaceae plant families. The site itself was dominated by herbaceous vegetation (grasses and sedges) at the time of coring, and its near environs by a largely shrubby vegetation, particularly Rhodomyrtus tomentosus, Leptospermum flavescens, Melastoma malabathrium and the ferns Dicranopteris linearis and Pteridium aquilinum. Danau di-Atas has a herbaceous marginal swamp, but large areas of 
lower montane forest are nearby, except in the vicinity of the town of Alahan Panjang, where rice cultivation and low regrowth predominates (Newsome and Flenley 1988; Fig. 1).

The soils near Pea Bullok derive from acidic rhyolitic Toba ashes, and although shallow, may have developed slowly since the last major volcanic eruption, $\mathrm{K}-\mathrm{Ar}$ dated at ca. $74 \mathrm{ka}$ (Chesner et al. 1991). The soils mainly resemble acid brown earths and podzols but large areas of surface water gleys allow wet rice cultivation. Newsome and Flenley (1988) did not describe the soils of the Danau di-Atas area but surface water gleys can be expected where wet rice is cultivated. The FAOUNESCO (1979) soil map of Southeast Asia shows the region dominated by humic andosols.

TABLE 1. Radiocarbon Dates from Pea Bullok and Danau di-Atas

\begin{tabular}{|c|c|c|c|c|}
\hline Lab no. & $\begin{array}{l}\text { Depth } \\
(\mathrm{cm})\end{array}$ & $\begin{array}{l}{ }^{14} \mathrm{C} \text { age } \\
\text { (yr BP) }\end{array}$ & $\begin{array}{l}\delta^{13} \mathrm{C} \\
(\% 0)^{*}\end{array}$ & Material \\
\hline \multicolumn{5}{|c|}{ Pea Bullok Core A } \\
\hline UB-3732 & $50-60$ & $3330 \pm 65$ & -29.8 & Herbaceous peat \\
\hline UB-3700 & $90-100$ & $7963 \pm 55$ & -29.7 & -- \\
\hline UB-3735 & $220-230$ & $14,485 \pm 72$ & -28.7 & Woody peat \\
\hline UB-3695 & $230-240$ & $11,798 \pm 69$ & -28.9 & Herbaceous peat \\
\hline UB-3701 & $300-310$ & $18,088 \pm 109$ & -28.1 & -- \\
\hline UB-3696 & $330-340$ & $20,081 \pm 106$ & -28.4 & -- \\
\hline UB-3644 & $440-450$ & $20,992 \pm 139$ & -27.0 & -- \\
\hline UB-3702 & $470-480$ & $21,379 \pm 249$ & -28.5 & -- \\
\hline OxA-3794 & $540-550$ & $24,140 \pm 260$ & -27.1 & Fine organic mud \\
\hline OxA-3240 & $720-725$ & $28,840 \pm 460$ & -27.2 & -- \\
\hline \multicolumn{5}{|c|}{ Pea Bullok Core B } \\
\hline UB-3694 & $40-50$ & $103.2 \mathrm{pMC} \pm 1.2$ & -28.8 & Fibrous \\
\hline UB-3697 & $110-120$ & $5132 \pm 53$ & -29.2 & -- \\
\hline UB-3733 & $130-140$ & $9273 \pm 51$ & -29.0 & -- \\
\hline UB-3734 & $140-150$ & $10,579 \pm 55$ & -28.9 & Fibrous woody peat \\
\hline UB-3698 & $170-180$ & $14,868 \pm 67$ & -27.7 & -- \\
\hline UB-3699 & $230-240$ & $17,859 \pm 107$ & -28.3 & Herbaceous peat \\
\hline UB-3736 & $300-310$ & $18,496 \pm 100$ & -28.7 & -- \\
\hline UB-3693 & $340-350$ & $19,263 \pm 121$ & -28.4 & Fine organic mud \\
\hline \multicolumn{5}{|c|}{ Danau di-Atas } \\
\hline SRR-1900 & $130-140$ & $4562 \pm 50$ & -27.3 & $\begin{array}{l}\text { Coarse herbaceous } \\
\text { detritus mud }\end{array}$ \\
\hline RR-1346 & $260-270$ & $6850 \pm 60$ & -27.0 & -- \\
\hline SRR-1347 & $525-535$ & $11,710 \pm 110$ & -26.7 & $\begin{array}{l}\text { Coarse woody } \\
\text { detritus mud }\end{array}$ \\
\hline SRR-1348 & $780-790$ & $13,160 \pm 170$ & -26.5 & -- \\
\hline SRR-1349 & $1055-1065$ & $16,930 \pm 170$ & -26.5 & -- \\
\hline GX-4915 & $1315-1325$ & $23,250 \pm 1220$ & $\begin{array}{l}\text { Not } \\
\text { available }\end{array}$ & $\begin{array}{l}\text { Coarse herbaceous } \\
\text { detritus mud }\end{array}$ \\
\hline SRR-1487 & $1375-1385$ & $21,180 \pm 580$ & -24.2 & Fine detritus mud \\
\hline SRR-1350 & $1415-1425$ & $18,250 \pm 290$ & -24.6 & -- \\
\hline SRR-1901 & $1460-1470$ & $22,370 \pm 320$ & -25.3 & $\begin{array}{l}\text { Fine detritus mud } \\
\text { with silt }\end{array}$ \\
\hline GX-4916 & $1560-1570$ & $31,450 \pm 2990$ & $\begin{array}{l}\text { Not } \\
\text { available }\end{array}$ & -- \\
\hline
\end{tabular}

${ }^{*} \delta^{13} \mathrm{C}$ uncertainty of UB dates $= \pm 0.2$; uncertainties of $\mathrm{OxA}, \mathrm{SRR}$ and $\mathrm{GX}$ values are not known. 


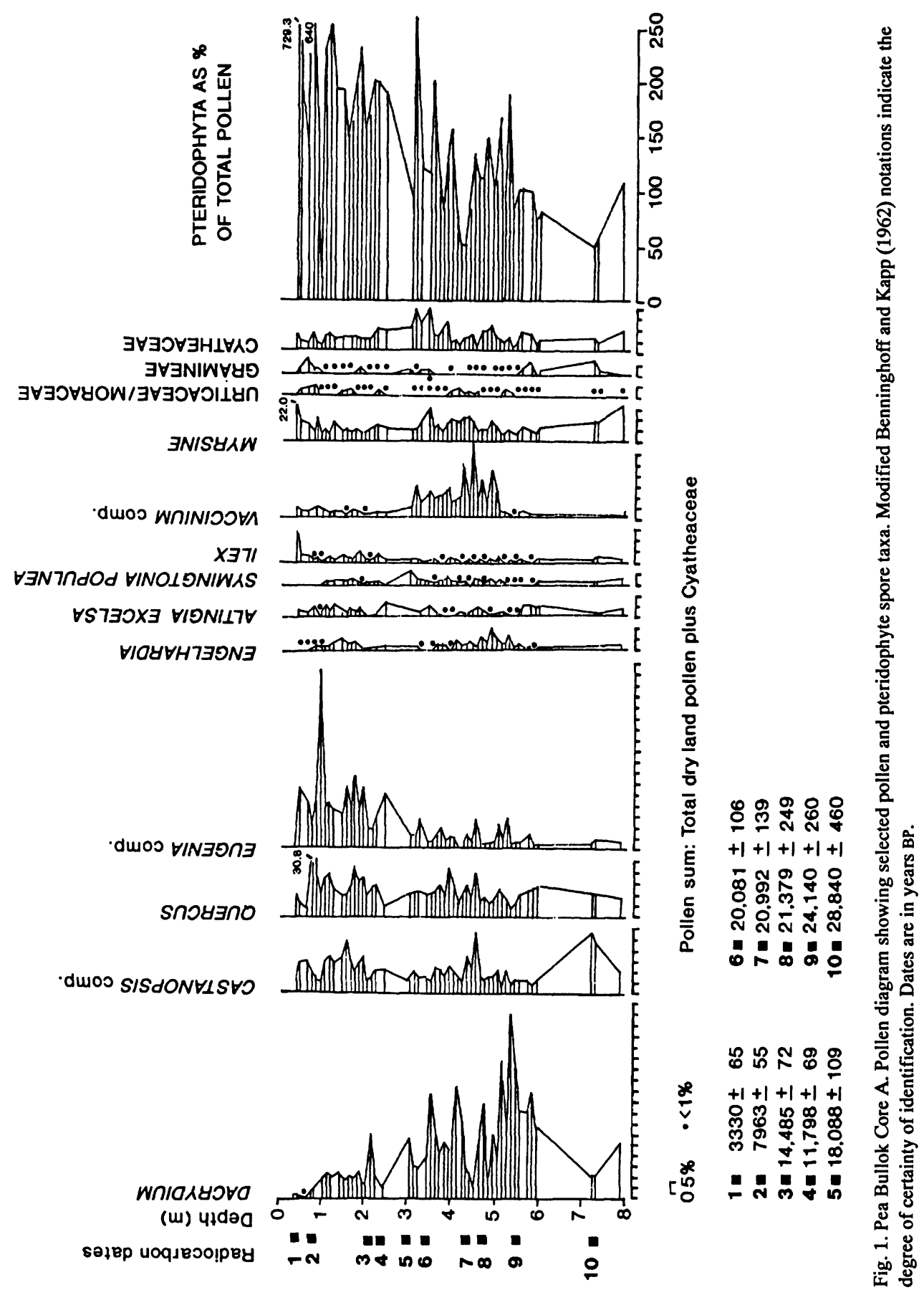




\section{METHODS}

Cores were collected from Pea Bullok using a Russian borer with a Dachnowsky piston sampler for the stiffer material. The 8-m depth was reached at the edge of the swamp during coring to record the stratigraphy and a few samples were saved from the last meter. Unfortunately, it was not possible to bore that deep again, so a gap exists between $6 \mathrm{~m}$ and $7.2 \mathrm{~m}$ depth. Poorly decomposed wood greatly hindered coring, a problem also met at Danau di-Atas (Newsome and Flenley 1988). A 6.5-m core was collected at Danau di-Atas in 1976 using a Russian borer, but a depth of $16.5 \mathrm{~m}$ was reached the following year using a Hiller sampler. The base of the deposits was not encountered in the cores from either Pea Bullok or Danau di-Atas.

Samples used for ${ }^{14} \mathrm{C}$ dating at both sites came from the cores used for pollen analysis. All the pollen samples were chemically pretreated by standard methods and mounted in silicone fluid. Lycopodium clavatum spores were added as per the method of Stockmarr (1971) to determine pollen concentration figures. This was fairly successful with Danau di-Atas material but not with the Pea Bullok samples, in which concentrations fluctuated widely among samples and the statistics are often unreliable. The pollen grains were identified using modern pollen reference slides and the literature. We interpreted the pollen diagrams by comparison against pollen counts from surface samples and by reference to ecological surveys and information contained in the botanical literature. The new OxA and UB dates have significantly assisted the interpretation.

\section{RESULTS AND DISCUSSION}

The pollen diagrams in Figures 1, 2 and 4, which show only selected pollen and pteridophyte spores, are the basis for the following outline of findings relating to the vegetation and climate changes of the last $30 \mathrm{ka}$. We also discuss the problems involved in correlating the diagrams from the two sites, with special reference to the GX and SRR series dates made earlier. We mention variations in the hydroseral vegetation only when the pollen taxa could be from either wet or dry land sources, as hydroseral vegetation is a poor indicator of climate trends.

\section{Pea Bullok Core A (Fig. 1)}

The oldest sample we analyzed is from $7.95 \mathrm{~m}$, with a probable age of $c a .32 \mathrm{ka}$ or older. The key pollen types are Dacrydium, Castanopsis comp., Quercus and Myrsine. Myrsine is often a subalpine indicator (Walker and Flenley 1979) but has been reported growing on swamps in the region (Polak 1933) where it may be a relict of colder, more open dryland conditions. Dacrydium elatum is a possible swamp forest taxon but is also present in lower montane forest. However, the general impression that this sample gives is of Fago-Lauraceous forest, such as the remnants existing in the region today. These indications of warm, wet conditions are offset by a low percentage of pteridophyte spores relative to total pollen suggestive of dryness (van der Kaars 1991), although there may be non-climatic explanations for this ratio.

The samples from the 7.20-7.23 m depth encompass the AMS date of $c a .29 \mathrm{ka}$ BP. Here, Dacrydium declines, Castanopsis comp. increases and the pteridophyta : pollen ratio is at almost its lowest for the whole diagram. Again, the indications are for a climate similar to present. The last glaciation may have begun ca. $27 \mathrm{ka} \mathrm{BP}$ (Sirocko et al. 1993), and the increase of Dacrydium in the pollen diagram is probably due to cooling. The pteridophyta : pollen ratio remains low, but increases at 5.45$\mathrm{m}$ depth (ca. $24 \mathrm{ka} \mathrm{BP}$ ) where there is a strong peak of Dacrydium and a rise in tree fern spores (Cyatheaceae), Engelhardia and Vaccinium comp. Here, clearly, climate grew colder and effective precipitation possibly increased. The amount of downslope movement in the vegetation belts is dif- 


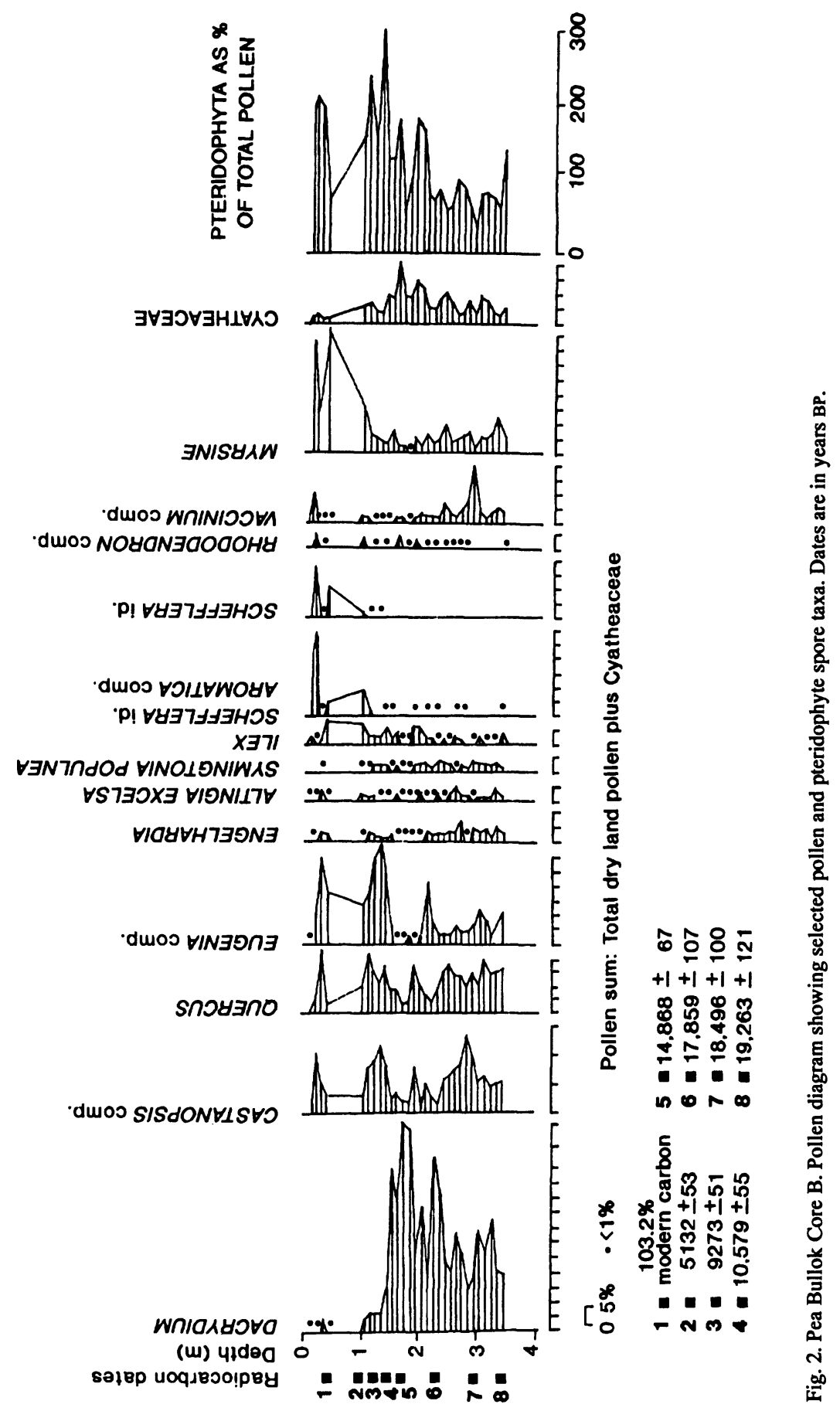


ficult to establish and inferences cannot easily be drawn, as no Sumatran pollen record contains distinctive tropic-alpine elements. Yamada (1977) found Engelhardia spicata most commonly at a ca. 1700-m elevation in West Java. The pollen was most frequent in surface samples from 1650-2395 $\mathrm{m}$ in central Sumatra (Newsome 1988). A downward movement of vegetation belts would have caused lowering in the montane cloud belt, but there is little information on the latter's general range except for Mount Kinabalu, Sabah, where it is at 1680-2150 m (Kitayama 1992).

The trend of Vaccinium comp. is most notable. Ericaceae can be a component of either swamp or dry-land vegetation, but the frequency of Vaccinium comp. in pollen records is usually low. Here the peaks tend to mirror troughs in the Dacrydium curve, probably reflecting periods of fluctuating colder subalpine or upper montane and warmer montane forest conditions. The Vaccinium curve indicates a general but inconsistent cooling trend with the major peak encompassing a ${ }^{14} \mathrm{C}$ age of $\mathrm{ca}$. $21 \mathrm{ka} \mathrm{BP}, 3 \mathrm{ka}$ earlier than that usually cited for the maximum cooling during the last glaciation. The oscillations between 24-21 ka BP are difficult to explain; moreover, correlations with the Danau diAtas diagram are problematic for this period because of the inverted dates from that site. It appears that temperatures declined while conditions remained fairly wet. However, this wetness may have been due to the lowering of the altitude of the cloud belt rather than any regional change in precipitation. In Africa, relict low-elevation montane forest is attributed to this effect (Maley et al. 1990). As glaciation caused lowered sea levels, the northeast monsoon would have had to pass over a much larger area of dry land than at present, resulting in a seasonally drier climate. A 100-m drop in sea level would not significantly increase the land area of western Sumatra, so the southwest monsoon may not have varied as much, although reduced temperatures may have increased effective precipitation. The largest frequency of Cyatheaceae spores occurs between $c a .20-18 \mathrm{ka} \mathrm{BP}$, and tree fern spores remained significant until the start of the Holocene, but Vaccinium comp. declined abruptly after $18 \mathrm{ka} \mathrm{BP}$, indicating climatic amelioration. Cyatheaceae are likely subalpine indicators (Walker and Flenley 1979).

The Holocene is characterized by a dominance of Fago-Lauraceous forest taxa, and the rise in Eugenia comp. pollen had a regional extent (Maloney 1985). Also the pteridophyta : pollen ratio is consistently high, probably reflecting climatic wetness (van der Kaars 1991). The last major peak of Dacrydium is associated with the inverted ${ }^{14} \mathrm{C}$ date of $c a .14 \mathrm{ka} \mathrm{BP}$. Because the core is from the margin of the site, this inversion may be due to erosion and redeposition of peat, possibly caused by slumping associated with earthquake activity. Hehanussa et al. (1987) claimed that substantial movement along faults ended ca. $17 \mathrm{ka}$ ago, but the last reported earthquake was in 1921 (Braak 1929).

A very pronounced peak of lower montane forest Eugenia occurs $c a .8 \mathrm{ka}$ BP. Thereafter, Urticaceae/ Moraceae and Gramineae, likely disturbance indicators, became more common, suggesting the beginnings of human impact on the vegetation. Important peaks of Myrsine and Ilex at ca. $3.3 \mathrm{ka} \mathrm{BP}$ may result from clearance of swamp forest and its replacement by scrub vegetation. The forest decline cannot be traced in detail because of poor sampling resolution.

\section{Pea Bullok Core B (Fig. 2)}

The 3.5-m-long Core B covers the last $20 \mathrm{ka}$. The main difference in the earlier part of the sequence is in the behavior of cold-indicating Vaccinium comp. An isolated peak occurs ca. $18 \mathrm{ka} \mathrm{BP}$, but the percentages are usually higher in Core A, suggesting a dryland origin. As in Core A, the main tree fern percentages postdate $18 \mathrm{ka} \mathrm{BP}$. Here the last major peak of Dacrydium is coeval with the European Younger Dryas and might indicate reversion to colder conditions, but much more research is needed to prove or disprove this. A brief change at Danau di-Atas may date to the same time period, 
but no ${ }^{14} \mathrm{C}$ dates cover the time between ca. $11.7 \mathrm{ka}$ and $6.8 \mathrm{ka} \mathrm{BP}$; Engelhardia, sometimes a disturbance indicator, became dominant in two pollen diagrams from elevations of 1300 and $1750 \mathrm{~m}$ at this time in West Java (Stuijts 1993).

The main increase in Eugenia comp., indicating climatic warming, began before ca. $10.6 \mathrm{ka}$ BP and the decline after $9.2 \mathrm{ka}$ BP and especially $5.1 \mathrm{ka} \mathrm{BP}$ (almost $6 \mathrm{ka} \mathrm{cal.} \mathrm{BP} \mathrm{(Stuiver} \mathrm{and} \mathrm{Reimer} \mathrm{1986))}$ when Schefflera id. aromatica comp. and Myrsine increased significantly. Both remain important at the top of the diagram, suggesting that forest clearance was taking place, but probably intensively only after ca. $2 \mathrm{ka}$ BP. Amaranthaceae pollen is present in two samples (Chenopodiaceae often have similar pollen grains but have not been reported from Sumatra) most abundantly from $0.77 \mathrm{~m}$ depth, which may be $3.4 \mathrm{ka}$ old. Amaranthaceae can be weeds of rice fields but may be more closely associated with root crops and some kind of dryland crop was probably being grown.

\section{Danau di-Atas (Fig. 4)}

The Pea Bullok diagrams can best be correlated with the Danau di-Atas diagram using ${ }^{14} \mathrm{C}$ dates, as the two sites vary in topography and therefore in sources of pollens. Unfortunately, published data do not permit recalculation of the pollen sum, which hinders correlation, but not nearly so much as the problems with dating. If the earlier Geochron dates, which may be of infinite age, are omitted from the sequence, the other dates show a 0.96 correlation and the estimated age of the base of the sequence becomes $26,830 \mathrm{BP}$ instead of $33,158 \mathrm{BP}$; inclusion of these dates brings the correlation down to 0.88 (Fig. 3).

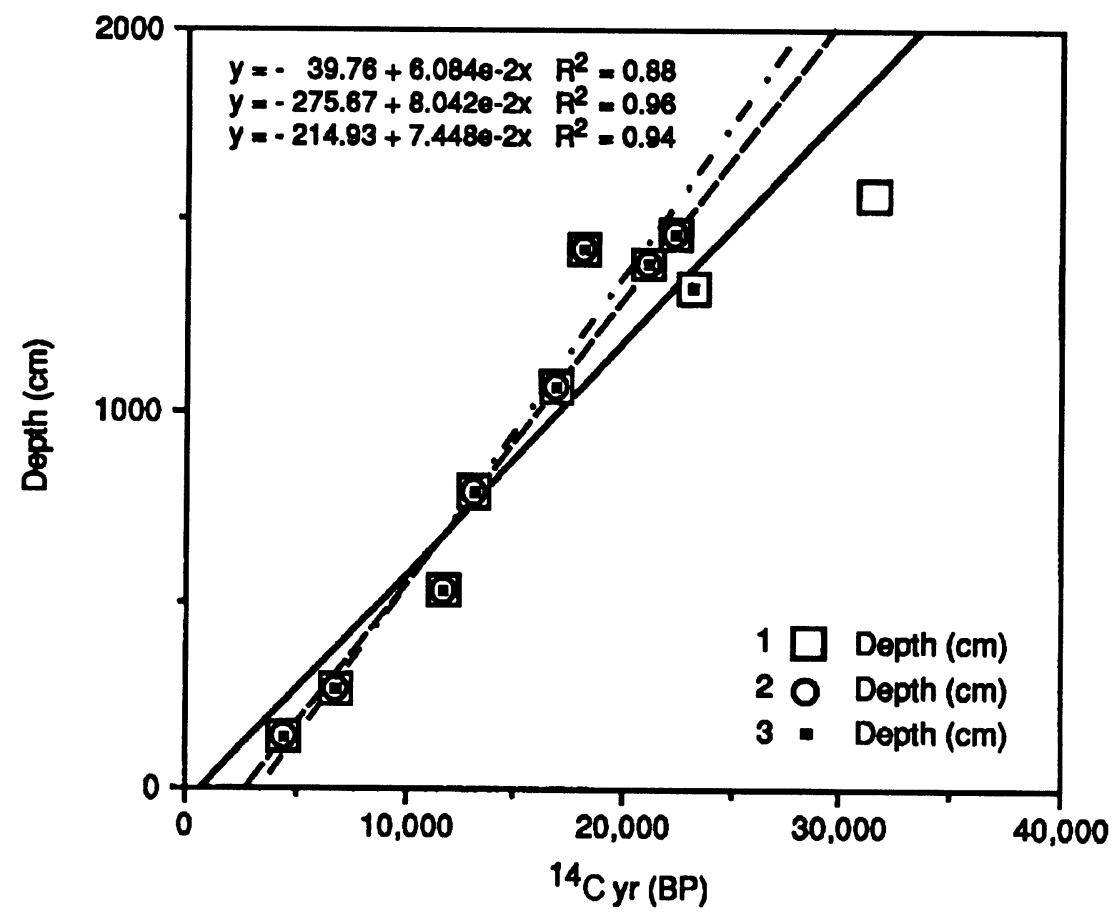

Fig. 3. Danau di-Atas: Regression of depth $v s .{ }^{14} \mathrm{C}$ dates, disregarding statistical uncertainties of the dates and omitting GX-4915 and GX-4916 
The main problem is GX-4916. If this is excluded, the correlation becomes 0.94 and the sedimentation rates show an exponential curve; otherwise a 5th-order polynomial curve is the best fit. The correlations of the two NERC Laboratory sequences are not significantly different from each other. Regardless of the dating problems and differing pollen sums, the most striking contrast between the Danau di-Atas and Pea Bullok diagrams is the frequency of Dacrycarpus imbricatus and Myrtaceae pollen in the older part of the former (Fig. 4). It is possible that this pollen is largely of local origin, swamp forest in the case of Myrtaceae. There are no significant late peaks of Myrsine and Ilex as at Pea Bullok, nor is Engelhardia ever important in the diagram. Dacrydium, with Dacrycarpus imbricatus (this tends to be an upper-montane forest species), is important longer possibly because Danau di-Atas is at a higher altitude than Pea Bullok. Cyatheaceae are only significant $c a .18 \mathrm{ka}$ when they were also important and an indicator of cold conditions at Pea Bullok. It is not possible to establish a pteridophyta : total pollen ratio without the original data from Danau di-Atas, so conclusions about changing wetness cannot be made.

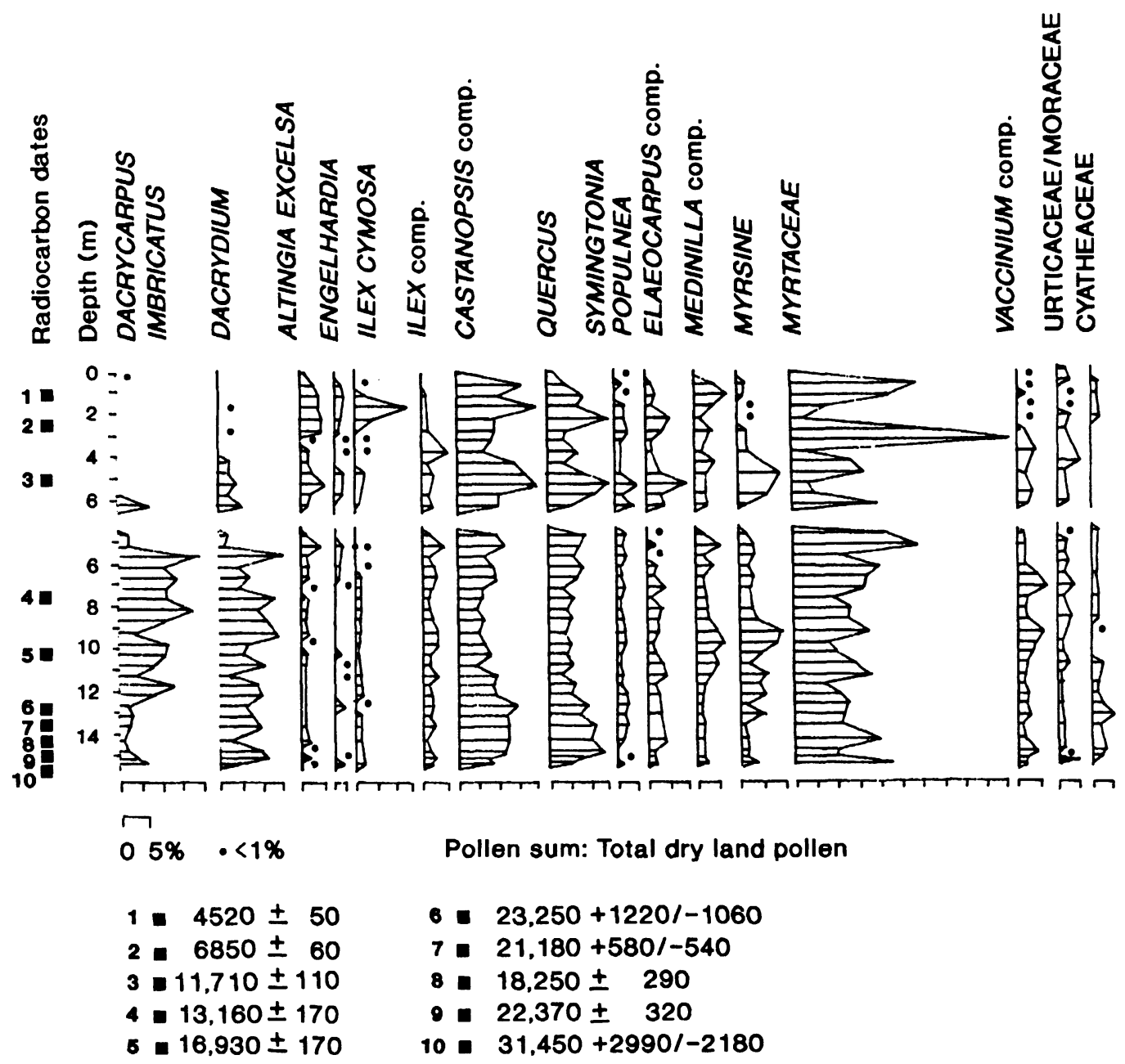

Fig. 4. Danau di-Atas. Pollen diagram showing selected pollen and pteridophyte spore taxa (modified from Newsome and Flenley (1988)). Dates are in years BP. 
Newsome and Flenley (1988) suggest that lower montane forest is represented below $13.15 \mathrm{~m}$ depth and that the inverted dates may result from a lowered lake level and erosion/redeposition of sediments. However, the site is in a rift valley, and an earthquake might produce a similar effect, but Hehanussa et al. (1987) placed the last major movements along faults in north Sumatra before $17 \mathrm{ka}$ BP. If the lake level was lower, it could have been from several causes: precipitation reduction; downcutting at the lake outlet by a river grading to a lowered glacial-period base level; and a lowered watertable. If the revised estimate of $c a .27 \mathrm{ka}$ is accepted for the base of the core, the interpretation that lower montane forest occurred is in agreement with findings from Pea Bullok, and the high Dacrydium percentages represent the same cooling trend. Newsome and Flenley (1988) proposed that the significant upper montane forest and ericoid element in the diagram between 13.15 and $7.40 \mathrm{~m}$ depth is linked to a $265 \mathrm{~m}$ (minimum) to $865 \mathrm{~m}$ (maximum) lowering in the altitude of the vegetation belts and a $1.6-5.2^{\circ} \mathrm{C}$ reduction in temperature. This is consistent with data from Pea Bullok, but Core B correlates better than Core $\mathrm{A}$ for the time period covered and a $5.2^{\circ} \mathrm{C}$ temperature decrease is more acceptable for the 24-21 ka period in north Sumatra. The latter vegetation lowering would put Danau di-Atas in the cloud belt and explains the lack of evidence for pronounced precipitation change. The 7.40-5.40-m section of the diagram shows an increase in lower montane forest elements, corresponding to temperatures of $c a .1 .6^{\circ} \mathrm{C}$ below present. A similar change occurs at Pea Bullok, but submontane forest elements were detected at between 1.90 and $0.20 \mathrm{~m}$ depth at Danau di-Atas, suggesting conditions more equable there than at present. Newsome and Flenley (1988) claimed that large-scale forest clearance postdated ca. $1.8 \mathrm{ka}$ BP, but Macaranga, often a clearance indicator, became more common above $3.40 \mathrm{~m}$ (i.e., after ca. $8.2 \mathrm{ka} \mathrm{BP}$ ). There were no indications of cultivar pollens. These findings bear comparison with the Pea Bullok record.

\section{Conclusion}

Because few sites have been examined, and because they vary in type, elevation, topography and local pollen sources, pollen diagrams from Sumatra can be directly correlated at present only by using ${ }^{14} \mathrm{C}$-dated sequences. Therefore, assessment of the reliability of the dates is very important. Pea Bullok and Danau di-Atas are the best dated sites analyzed and a reconsideration of the Danau di-Atas dates has made a more convincing correlation of the two pollen sequences possible. However, this would be easier with more dates from levels above the 10-m depth of Danau di-Atas, new AMS dates from its base, and publication of the raw pollen data. Both sites present clear evidence for profound glacial-period temperature change; there is less evidence for the early impact of people on the forest, but strong indications of extensive forest clearance postdating 2-1.8 ka BP.

\section{ACKNOWLEDGMENTS}

The AMS dating of the Pea Bullok Core A was carried out at Oxford University under the direction of Dr. Rupert Housley and funded by the School of Geosciences at Queen's University. The map and diagrams were drawn by Gill Alexander of the School of Geosciences at Queen's University and the Pea Bullok cores were collected while B. K. M. was in receipt of an NERC award at Hull University.

\section{REFERENCES}

Benninghoff, W. S. and Kapp, R. O. 1962 Suggested notations to indicate identification status of fossil pollen. Pollen et Spores 4: 332.

Boerma, J. 1925 Regenval in Nederlandisch-Indie. Verhandelingen Koninklijk Magnetisch en Meteorologisch Observatorium te Batavia 24(1): 1-192.
Braak, C. 1925 Het klimaat van Nederlandisch-Indie. Verhandelingen Koninklijk Magnetisch en Meteorologisch Observatorium te Batavia 8(1): 2.

1929 Earthquakes. In Rutten, L. M. R. ed., Science in the Netherlands East Indies. Amsterdam, Scheltens \& Giltay: 75-79. 
Chesner, C. A., Rose, W. I., Drake, A. D. R. and Westgate, J. A. 1991 Eruptive history of Earth's largest Quaternary crater (Toba Indonesia) clarified. Geology 19: 200-203.

FAO-UNESCO 1979 Soil Map of the World 1:500,000, Vol. 9, Southeast Asia. Paris, UNESCO.

Fontanel, J. and Chantefort, A. 1978 Bioclimats du monde Indonesien. Travaux de la Section Scientifique et Technique, Institut Français de Pondichery 16: 104 p.

Hehanussa, P. E., Fujii, S., and Yokoyama, T. $1987 \mathrm{New}$ dates of fluvio-lacustrine deposit around Lake Toba, Indonesia. International Project on Palaeolimnology Newsletter 4: 17-20.

Kitayama, K. 1992 An altitudinal transect study of the vegetation on Mount Kinabalu, Borneo. Vegetatio 102: 149-171.

Maley, J., Caballe, G. and Sita, P. 1990 Etude d'un peuplement residuel à basse altitude de Podocarpus latifolius sur le flanc congolais du massif du Chaillu. Implications paléoclimatiques et biogéographiques. Etude de la pluie pollinique actuelle. In Lanfranchi, R. and Schwartz, D., eds., Paysages Quaternaires de l'Afrique Centrale Atlantique. Paris, Orstom: 336-352.

Maloney, B.K. 1985 Man's impact on the vegetation of West Malesia. Journal of Biogeography 12: 537-558.

Newsome, J. 1988 Late Quaternary vegetational history of the Central Highlands of Sumatra. I: Present vegetation and modern pollen rain. Journal of Biogeography 15: 363-386.

Newsome, J. and Flenley, J. R. 1988 Late Quaternary vegetational history of the Central Highlands of Sumatra.
II. Palaeopalynology and vegetational history.Journal of Biogeography 15: 555-578.

Polak, E. 1933 Ueber Torf und Moor in Niederlandisch Indien. Verhandlingen der Koninklijke Acadamie van Wetenschappen, Tweede Sectie 30(3): 1-85.

Sirocko, F., Sarnthein, M., Erlekeuser, H., Lange, H., Arnold, M. and Duplessy, J. C. 1993 Century-scale events in monsoonal climate over the last 24,000 years. Nature $364:$ 322-324.

Stockmarr, J. 1971 Tablets with spores used in absolute pollen analysis. Pollen et Spores 13: 615-621.

Stuijts, I.-L. M. 1993 Late Pleistocene and Holocene Vegetation of West Java, Indonesia. Rotterdam, Balkema: $183 \mathrm{p}$.

Stuiver, M. and Reimer, P. J. 1986. A computer program for radiocarbon age calculation. In Stuiver, $M$. and Kra, R. S., eds., Proceedings of the 12th International ${ }^{14} \mathrm{C}$ Conference. Radiocarbon 28(2B): 1022-1030.

van der Kaars, W. A. 1991 Palynology of eastern Indonesian marine piston-cores: A Late Quaternary vegetational and climatic record for Australasia. Palaeogeography, Palaeoclimatology, Palaeoecology 85: 239-302.

Walker, D. and Flenley, J. R. 1979 Late Quaternary vegetational history of the Enga district of upland Papua New Guinea. Philosophical Transactions of the Royal Society, London B 286: 265-344.

Yamada, I. 1977 Floristic ecological studies of the montane forest of Mt. Pangrango, west Java IV: Floristic composition along the altitude. South East Asian Studies, Kyoto University 15: 226-254. 